\title{
Poradniki metodyczne jako źródło wiedzy nauczycieli w edukacji wczesnoszkolnej
}

\section{Klasyfikacja i struktura przewodników metodycznych}

Przewodniki metodyczne są po programach i podręcznikach dla ucznia jednym z najczęściej wykorzystywanych rodzajów literatury, który w zdecydowany sposób wpływa na przebieg procesu dydaktyczno-wychowawczego we współczesnej edukacji. W pracy nauczyciele natrafiają na liczne trudności i chcąc je pokonać sięgają do odpowiednich publikacji w poszukiwaniu konkretnych wskazówek umożliwiających rozwiązanie zaistniałych sytuacji dydaktycznych i wychowawczych. Opracowania muszą więc być dostosowane do potrzeb czytelników o różnym poziomie i powinny zawierać różnorodne rozwiązania metodyczne.

Opracowania metodyczne, ze względu na zakres ujmowanego materiału można klasyfikować na cząstkowe i całościowe. Do opracowań cząstkowych, zwanych też małymi formami metodycznymi, należą:

- plan lekcji,

- konspekt lekcji,

- protokół lekcji,

- analiza metodyczna tematu,

- analiza metodyczna grupy tematów,

- analiza metodyczna działu programowego ${ }^{1}$.

Małe formy metodyczne dotyczą najczęściej jednego tematu lub przedstawiają kilka wariantów rozwiązania jednego problemu edukacyjnego. Wariantowość ma wartość wtedy, gdy każde $\mathrm{z}$ tych rozwiązań uwzględnia inne założenia dydaktyczne np. jedno ogranicza zadanie ucznia do opanowania materiału informacyjnego, inne uwypukla problemowość i kształcenie umiejętności myślenia, jeszcze inne kieruje wysiłek ucznia na rozwijanie praktycznego zastosowania nowvch umiejętności, przy czym każde z nich wymaga innego „oprzyrządowania” dydaktycznego, innego wyposażenia w pomoce dydaktyczne ${ }^{2}$.

\footnotetext{
${ }^{1}$ T. Nowacki, Teoretyczne podstawwy opracowań metodycznych, Wrocław 1976, s. 61.

${ }^{2}$ Tamże, s. 54.
} 
Plan lekcji obejmuje zazwyczaj następujące punkty: temat lekcji, założone do zrealizowania cele dydaktyczne i wychowawcze, wyrażone najczęściej w kategoriach konkretnych czynności, jakie w wyniku lekcji mają być opanowane przez uczniów, porządek lekcji, na który składają się czynności przygotowawcze, czynności podstawowe, których rodzaj zależy od typu lekcji oraz czynności końcowe, do których należy zwykle utrwalenie przerobionego na lekcji materiału oraz zadanie uczniom pracy domowej ${ }^{3}$.

Konspekt jest szczegółowym rozwinięciem planu lekcji. Obecnie częściej używa się pojęcia scenariusz. W literaturze pojęcia konspekt oraz scenariusz czasami funkcjonują w zróżnicowanej interpretacji. Konspektowi zarzuca się sformalizowanie, zbytnie eksponowanie roli nauczyciela, ograniczenia aktywności ucznia, schematyzm.

Twórczy, kreatywny aspekt dzisiejszej edukacji, wyrażany w autorskich rozwiązaniach nauczyciela i aktywnej postawie ucznia, formalny zapis pracy przygotowującej nauczyciela do lekcji powinien być zgodny przede wszystkim z osobistymi potrzebami jego twórcy. Nie ma znaczenia czy nazwiemy go scenariuszem czy konspektem ${ }^{4}$.

Cz. Kupisiewicz wyjaśnia: konspekt jest szczegółowym rozwinięciem planu lekcji. Obejmuje on zwykle takie punkty, jak: temat, cele i zadania lekcji, jej porzqdek wraz z rozbiciem na poszczególne etapy, temat pracy domowej, a ponadto przewidywane pytania nauczyciela $i$ uczniów. Oprócz tego w konspekcie zamieszcza się rejestr tych metod i środków dydaktycznych, które maja być zastosowane $w$ poszczególnych etapach jej realizacji. W konspekcie umieszcza się też materiaty dodatkowe np. zestawy ćwiczeń dla uczniów pracujacych szybciej.

D. Gołębniak małe formy metodyczne takie jak plan lekcji, konspekt i scenariusz traktuje tożsamo. Twierdzi, że „nie istnieje jeden format pisemnego planu zajęć. Zależy on zawsze od poziomu i obszaru edukacji, zwyczajów przyjętych w danej szkole, indywidualnych preferencji nauczyciela. Niektórzy nauczyciele, by móc myśleć kreatywnie, ograniczają zapis do minimum; inni są przekonani, że umieszczenie w scenariuszu czy konspekcie wielu szczegółów sprzyja koncentracji i kreatywnemu myśleniu czy działaniu 6 .

Do opracowań cząstkowych zalicza się też prace ogarniające więcej niż jeden temat, zawierające teoretyczną analizę lub praktyczne projekty rozwiązań pewnej grupy tematów, działu programowego. Protokół przeprowadzonej lekcji

${ }^{3}$ Cz. Kupisiewicz, Podstawy dydaktyki ogólnej, Warszawa 1996, s. 285.

${ }^{4}$ B. Dudzińska, Cele kształcenia w edukacji wczesnoszkolnej, „Życie Szkoły” 2006, nr 4, s. 9.

${ }^{5}$ Cz. Kupisiewicz, Podstawy..., s. 246.

${ }^{6}$ D. Gołębniak, Nauczanie i uczenie się w klasie, [w:] Z. Kwieciński, B. Śliwerski, (red.), Pedagogika, tom 2, Warszawa 2003, s. 192. 
opisuje czynności nauczyciela oraz czynności i reakcje uczniów. Przedstawia obraz żywego procesu dydaktycznego

Opracowania cakościowe obejmują materiał nauczania zawarty w programie. Są bardziej lub mniej usystematyzowane i posiadają określoną konstrukcję. Należą do nich :

- poradnik metodyczny,

- przewodnik metodyczny,

- podręcznik metodyczny,

- zarys metodyki,

- monografia metodyczna ${ }^{7}$.

Poradniki metodyczne zawierają opracowanie tych zagadnień, które autor uważa za trudne. Ich celem jest pomoc nauczycielowi, poradnik zawiera najczęściej całość jakiegoś pomocniczego zakresu, z reguły nie podejmuje ośrodkowej tematyki metodycznej.

Przewodnik metodyczny to opracowanie, które opierając się na programie podaje temat po temacie wraz ze wskazówkami metodycznego rozwiązania. Najbardziej wartościowym przewodnikiem jest taki, który opiera się na wyraźnej koncepcji teoretycznej. Od nauczyciela zależy czy wykona wszystkie jednostki lekcyjne, czy wykorzysta tylko niektóre lub wprowadzi rozmaite odmiany. Przewodniki metodyczne zawierają niezbyt obszerną podbudowę teoretyczna.

Podręcznik metodyczny jest opracowaniem, w którym autor przeprowadza teoretyczne uzasadnienie rozwiązań, ilustrując je odpowiednimi, konkretnymi przykkadami. O współczesnym podręczniku metodycznym decyduje przeprowadzenie w części teoretycznej analizy struktury materiału nauczania ${ }^{8}$. Podręcznik metodyczny przedstawia nauczycielowi wszystkie potrzebne elementy teoretyczne tak, aby on sam mógł na tej podstawie poprawnie budować scenariusze i plany lekcji. Rozważania struktury programu nauczania zawierają równocześnie sporą porcję wiedzy przedmiotowej. Przykłady rozwiązań metodycznych poszczególnych tematów w podręczniku metodyki spełniają funkcję modeli, a nie wzorów do naśladowania. Celem takich podręczników jest doskonalenie umiejętności metodycznych nauczycieli.

Nazwa zarys metodyki odnosi się do opracowań, w których prezentowana jest konstrukcja programu, obejmująca pewną całość oraz szkicowo zaznaczone niektóre jego fragmenty. Zawiera rozważania teoretyczne i przepisy praktyczne oraz sporą ilość przykładów.

Monografia metodyczna to podręcznik metodyczny o nienagannej konstrukcji teoretycznej, wyczerpujący problematykę metodyczną przedmiotu nauczania współczesną i historyczną, uwzględniający przewidywane zmiany i aktualizacje. Monografię cechuje znaczna trwałość. Przez długie lata wpływa na metody nauczania i uczenia się danego przedmiotu.

\footnotetext{
${ }^{7}$ T. Nowacki, Teoretyczne..., s. 61.

${ }^{8}$ Tamże, s. 58.
} 
Kryterium zawartości podbudowy teoretycznej pozwala wyróżnić opracowania czysto praktyczne: plany i konspekty lekcji, protokoły, poradniki metodyczne i większość przewodników metodycznych oraz opracowania teoretyczno-praktyczne: analizy metodyczne poszczególnych tematów i grup tematycznych, analizy metodyczne działów programowych, materiały metodyczne, zarysy metodyk, podręczniki metodyczne.

Ze względu na kryterium wariantowości wyróżniamy opracowania jednowariantowe i wielowariantowe. Przewodniki wielowariantowe, zawierające różne układy metodyczne bez poważnego uzasadnienia teoretycznego. Celem takiego przewodnika jest wdrażanie nauczycieli do korzystania z rozmaitych rozwiązań i rozwijania umiejętności posługiwania się różnorodnymi metodami.

Opracowania metodyczne mają najczęściej układ blokowy. Ich konstrukcja przedstawia się następująco:

I. Funkcja dydaktyczna przedmiotu.

II. Analiza struktury treści.

III. Tematy lekcyjne i warianty projektów rozwiązań metodycznych.

IV. Analiza wyników nauczania.

Analiza funkcji określa znaczenie danego tematu dla opanowania przez uczniów całego programu. Określa i charakteryzuje cele nauczania określonego przedmiotu.

Analiza struktury treści przedstawia związki jakie zachodzą między treściami, hasłami programowymi. Wyłania $\mathrm{z}$ materiału nauczania główne, ośrodkowe problemy wokół których rozkładają się pozostałe treści. Nauczyciel przestaje traktować wszystkie tematy jednoplanowo. Nauczanie uwzględniające strukturę i uwypuklające zagadnienia węzłowe i dopełniające, pomaga uczniom w wytwarzaniu w świadomości obrazu struktury wiedzy, a w ślad za tym pomaga w swobodniejszym nią operowaniu $\mathrm{i} w$ rozwijaniu umiejętności jej zastosowań ${ }^{9}$. Opracowanie metodyczne zawierające taka analizę dobrze służy czytelnikom. Każdy nauczyciel posiada orientację w strukturze materiału nauczania, ale od takiej ogólnej orientacji odróżniamy wyniki gruntownej analizy, dającej szczegółowy wgląd $\mathrm{w}$ związki praw i pojęć fundamentalnych z pojęciami i prawami zależnymi oraz ugrupowaniem konkretyzacji i przykładów ${ }^{10}$.

Na podstawie powyższych analiz można zastosować właściwe rozwiązania metodyczne. Blok III może przedstawiać jeden lub kilka modeli rozwiązań metodycznych każdego tematu, bądź tylko głównego i kilku wybranych. Ukazywanie różnych sposobów rozwiązywania jednego tematu powinno zachęcić nauczycieli do własnych poszukiwań. Należy mieć na uwadze to, iż ważniejsze jest obdarzenie nauczyciela kluczami do rozwiązywania problemów metodycznych niż gotowymi rozwiązaniami.

\footnotetext{
${ }^{9}$ T. Nowacki, Teoretyczne..., s. 99.

${ }^{10} \mathrm{R}$. Radwiłowicz (red), Treści nauczania a rozwijanie samodzielności, Warszawa 1974 ,
} s. 132. 
Analiza wyników nauczania czyli kontrola i ocena pracy ucznia są ważną częścią każdego opracowania metodycznego. Służą one nie tylko do sprawdzania postępów uczniów, ale i samokontroli nauczyciela, pozwalają orientować się w jakości i wynikach własnego wysiłku. Znane są cztery metody sprawdzania wiedzy ucznia: odpowiedź ustna, prace pisemne, zadania praktyczne, obserwacja uczniów w toku pracy, która pozwala interpretować oceny i ustalić przeszkody w uzyskaniu przez ucznia dobrego wyniku.

Blok zawierający projekty wyposażenia pracowni ukazują właściwe wyposażenie w środki dydaktyczne i inne materiały edukacyjne. Niektóre opracowania metodyczne zawierają też blok zaznajamiający ze środkami zaradczymi w stosunku do uczniów opóźniających się w nauce i możliwościami pracy z uczniami wybiegającymi ponad przeciętną. Wad istotnych elementów prawidłowego opracowania metodycznego zależy od właściwości przedmiotu i jego miejsca w zespole przedmiotów.

Planowanie pracy i projektowanie zajęć szkolnych jest jednym z najważniejszych zadań podejmowanych przez nauczycieli. To działanie ma wpływ na efektywność systemu pracy dydaktyczno-wychowawczej szkoły. Skuteczne planowanie wymaga od nauczyciela wielu kompetencji dydaktyczno-metodycznych. Jak podkreśla W. Strykowski wcześniejszego planowania wymaga tworzenie własnych programów nauczania poszczególnych przedmiotów i ścieżek edukacyjnych, projektowanie scenariuszy zajęć dydaktycznych, projektowanie programu wychowawczego szkoły, projektowanie testów i innych narzędzi do mierzenia osiaggnięć uczniów, projektowanie procedur i narzędzi poznawania uczniów oraz ich środowiska, projektowanie planów doskonalenia i własnego rozwoju zawodowego ${ }^{11}$.

\section{Poradniki metodyczne jako źródło wiedzy metodycznej nauczycieli w edukacji wczesnoszkolnej w świetle badań własnych}

Stosowane przez nauczyciela rozwiązania metodyczne z pewnością zależą od jego kompetencji dydaktycznych, zdobywanych w trakcie studiów oraz w toku doskonalenia zawodowego. Dobór sposobów pracy zależy od nauczyciela. On to planując realizację określonych zadań i celów powinien uwzględniać szereg istotnych czynników, jak: wiek ucznia, właściwości poszczególnych rodzajów edukacji, dostępność środków dydaktycznych, otaczające środowisko, odpowiedni dobór metod nauczania, które to elementy w największym zakresie wywołają poznawczą, emocjonalną i praktyczną aktywność uczniów.

$\mathrm{W}$ praktyce szkolnej bowiem z pewnością nie chodzi o to, aby precyzyjnie deklamować zasady $i$ założenia określonej metody nauczania $i$ trzymać się

${ }^{11}$ W. Strykowski, Szkoła wspótczesna i zachodzace w niej procesy, [w:] J. Pielachowski, W. Strykowski, J. Strykowska, Kompetencje nauczyciela szkoły wspótczesnej, Poznań 2003, s. 75. 
instrukcji i przepisów. Warto znać wiele różnych metod, technik, sposobów rozwiazywania określonych problemów. Najważniejsze, to osiagnać porozumienie z uczniem i zrealizować określony cel. Zależy to od wrażliwości, kreatywności i otwartości nauczyciela ${ }^{12}$.

Wartość materiałów dydaktycznych dostępnych na rynku wydawniczym jest bardzo zróżnicowana pod względem merytorycznym i metodycznym. Jakie są walory tychże publikacji w oczach samych pedagogów wczesnoszkolnych miała dać odpowiedź ankieta przeprowadzona wśród nauczycieli pracujących z dziećmi w klasach I-III. Próba badawcza obejmowała grupę 32 nauczycieli pracujących w różnych szkołach miejskich i wiejskich województwa kujawsko-pomorskiego. Wszyscy badani nauczyciele mieli wyższe wykształcenie. Szczegółową charakterystykę badanej grupy prezentuję w tabeli 1 .

Tabela 1. Charakterystyka badanych nauczycieli

\begin{tabular}{|c|c|c|c|c|c|c|c|c|c|c|c|}
\hline \multirow{2}{*}{$\begin{array}{c}\text { Liczba } \\
\text { badanych }\end{array}$} & \multicolumn{4}{|c|}{ Staż pracy nauczycielskiej w latach } & \multicolumn{3}{c|}{ Stopień awansu zawodowego } & \multicolumn{2}{c|}{ Miejsce pracy } \\
\cline { 2 - 13 } & $0-5$ & $6-10$ & $11-15$ & $16-20$ & $\begin{array}{c}21 \mathrm{i} \\
\text { więcej }\end{array}$ & staż. & kontr. & mian. & dypl. & miasto & wieś \\
\hline 32 & 3 & 7 & 9 & 6 & 7 & 0 & 5 & 21 & 6 & 9 & 23 \\
\hline $100 \%$ & 9,3 & 21,9 & 28,1 & 18,8 & 21,9 & 0 & 15,6 & 65,6 & 18.8 & 28,1 & 71,8 \\
\hline
\end{tabular}

Jak wynika z zestawienia liczniejszą grupę stanowiły nauczycielki pracujące na wsi. Respondentki charakteryzował też zróżnicowany staż pracy, zdecydowana większość to jednak osoby z dużym doświadczeniem zawodowym.

Celem badań była ocena przewodników metodycznych wykorzystywanych w pracy pedagogów. Nauczyciele wskazali na cztery tytuły pakietów edukacyjnych stosowanych przez nich w pracy. Jak rozkładały się wybory przedstawiam w tabeli 2.

Tabela 2. Pakiety edukacyjne wykorzystywane przez badanych nauczycieli

\begin{tabular}{|c|c|c|c|c|c|c|}
\hline \multirow{3}{*}{$\begin{array}{c}\text { Tytuł } \\
\text { i wydawnictwo }\end{array}$} & \multicolumn{6}{|c|}{ Środowisko badanych nauczycieli } \\
\hline & \multicolumn{2}{|c|}{ Miasto } & \multicolumn{2}{|c|}{ Wieś } & \multicolumn{2}{|c|}{ Razem } \\
\hline & $\mathrm{L}$ & $\%$ & $\mathrm{~L}$ & $\%$ & $\mathrm{~L}$ & $\%$ \\
\hline Wesoła szkoła (WSiP) & 0 & 0 & 18 & 56,2 & 18 & 56,2 \\
\hline Już w szkole (Nowa Era) & 6 & 18,8 & 0 & 0 & 6 & 18,8 \\
\hline $\begin{array}{l}\text { Moja szkoła (MAC } \\
\text { Edukacja) }\end{array}$ & 0 & 0 & 4 & 12,5 & 4 & 12,5 \\
\hline $\begin{array}{l}\text { Z Ekoludkiem w szkole } \\
\text { (Żak) }\end{array}$ & 3 & 9,4 & 1 & 3,1 & 4 & 12,5 \\
\hline Razem & 9 & 28,2 & 23 & 71,8 & 32 & 100,0 \\
\hline
\end{tabular}

${ }^{12}$ M. Taraszkiewicz, Jak uczyć lepiej? Czyli refleksyjny praktyk $w$ działaniu, Warszawa 2001, s. 83 . 
Prezentowane w tabeli 2 zestawienie jednoznacznie wskazuje na preferencje badanych nauczycieli co do wybieranych pakietów edukacyjnych oraz związanych z nimi ściśle przewodników metodycznych. Zdecydowana większość wybrała materiały proponowane przez wydawnictwo WSiP zatytułowane „Wesoła Szkoła”.

Interesujący był zatem fakt określenia powodów, dla których takie a nie inne przewodniki były preferowane przez badanych nauczycieli. Sposób zaopatrywania się $\mathrm{w}$ materiały dydaktyczne prezentuję $\mathrm{w}$ kolejnym zestawieniu (tabela 3).

Tabela 3. Sposób zaopatrywania się w materiały dydaktyczne

\begin{tabular}{|l|c|c|}
\hline \multicolumn{1}{|c|}{ Źródło pozyskiwania materiałów } & L* & $\%$ \\
\hline od wydawcy podręczników & 30 & 93,4 \\
\hline od koleżanki z klasy wyższej & 27 & 84,4 \\
\hline z biblioteki szkolnej & 12 & 37,5 \\
\hline z księgarni & 2 & 6,3 \\
\hline
\end{tabular}

*Każdy nauczyciel miał prawo wyboru kilku odwiedzi

Jak wynika $\mathrm{z}$ analizy danych przedstawionych w tabeli 3 wybór określonego pakietu zależy od kilku czynników. Nie bez znaczenia są działania marketingowe wydawnictw. WSiP i MAC Edukacja docierają do szkół za pośrednictwem swoich przedstawicieli. Bezpośredni kontakt z zainteresowanymi, wzbogacenie oferty o różnorodne pomoce i materiały dla nauczyciela stanowią oczywistą zachętę do wyboru właśnie tego podręcznika. 93,4\% badanych wskazało wydawcę jako źródło zaopatrzenia się w materiały dydaktyczne. Nauczyciele chętnie dzielą się ze sobą doświadczeniem i wiedzą. Często też pożyczają sobie wzajemnie przewodniki i materiały. Taką odpowiedź wybrało $84,4 \%$ ankietowanych. Innym znaczącym źródłem zaopatrzenia jest biblioteka szkolna (37,5\%). Tylko 6,3\% badanych w materiały metodyczne kupuje w ksiegarni. Odpowiedzi takiej udzielili nauczyciele pracujący w mieście.

Poddając analizie inne możliwości przygotowywania się do zajęć, zapytałam nauczycieli, czy poza wyszczególnionymi przeze mnie pakietami edukacyjnymi korzystają z innych źródeł wiedzy merytorycznej i metodycznej. Wyniki zebrałam w tabeli 4.

Duża grupa nauczycieli w swojej pracy wspomaga się informacjami zawartymi w czasopiśmie „Życie Szkoły" (71,8\%), Internecie $(71,8 \%)$, w różnego rodzaju encyklopediach, słownikach (po 46,9\%) oraz w poradnikach przedmiotowych WSiP (43,8\%). Prawiepołowa ankietowanych korzysta $\mathrm{z}$ biuletynu 
„Pomagamy uczyć”, który dostarcza bezpłatnie wszystkim nauczycielom pracującym na ich podręcznikach wydawnictwo WSiP. Wyniki wskazują, że nauczyciele nie ograniczają się tylko do przewodników metodycznych związanych $\mathrm{z}$ wybranym pakietem. W celu urozmaicenia zajęć, wspierają się materiałami dodatkowymi w formie biuletynów, najświeższych informacji pochodzących z internetu czy forów internetowych specjalnie stworzonych dla nauczycieli. Korzystają też z albumów oraz opracowań i książek prezentujących aktywizujące metody i techniki pracy z uczniami.

Tabela 4. Inne źródła wiedzy merytorycznej i metodycznej

\begin{tabular}{|l|c|c|}
\hline \multicolumn{1}{|c|}{ Inne wymienione przez nauczycieli źródła } & $\mathrm{L}^{*}$ & $\%$ \\
\hline Życie Szkoły - czasopismo & 23 & 71,8 \\
\hline Internet & 23 & 71,8 \\
\hline Encyklopedie & 15 & 46,9 \\
\hline Słowniki & 15 & 46,9 \\
\hline Poradniki przedmiotowe WSiP & 14 & 43,8 \\
\hline Pomagamy uczyć - biuletyn nauczycielski & 13 & 40,6 \\
\hline Nauczanie Początkowe - kwartalnik & 12 & 37,5 \\
\hline Z Ekoludkiem w szkole - biuletyn informacyjny & 10 & 31,3 \\
\hline Albumy & 10 & 31,3 \\
\hline Inne pozycje książkowe wydawnicywa Żak & 9 & 28,1 \\
\hline Wszystko dla szkoły - czasopismo & 9 & 28,1 \\
\hline Wydawnictwa KLANZY & 8 & 25,0 \\
\hline Publikacje metodyczne WSiP & 5 & 15,6 \\
\hline Publikacje pomocnicze np. ,Matematyka z uśmiechem" & 3 & 9,4 \\
\hline Forum nauczycieli & 3 & 9,4 \\
\hline 45 minut - kwartalnik & 3 & 9,4 \\
\hline
\end{tabular}

*Pytanie otwarte - stąd liczba wszystkich odpowiedzi nie sumuje się do 100\%

W dalszej część badań skupiłam się na zebraniu opinii na temat rozwiązań metodycznych proponowanych w przewodnikach. W analizie wyników odniosłam się do lat pracy i stopnia awansu zawodowego nauczycieli. W tabeli 5 . Przedstawiam dane związane $\mathrm{z}$ odpowiedziami nauczycieli na zagadnienie modyfikowania przez nich zastanych w poradnikach scenariuszy zajęć.

Uzyskane wyniki wskazują, że zmian dokonują częściej nauczyciele doświadczeni, z wieloletnim stażem pracy. Wszyscy badani w przedziale do 20 lat pracy i 57,2\% powyżej 20 lat czasami zmieniają proponowane plany zajęć. 42,8\% ankietowanych, których staż pracy wynosi więcej niż 20 lat modyfikują scenariusze często. Istotne było również rozróżnienie tej kwestii jeśli chodzi o stopień awansu zawodowego. Przestawiam to w tabeli 6 . 
Tabela 5. Częstotliwość modyfikacji scenariuszy z uwzględnieniem stażu pracy nauczyciela

\begin{tabular}{|c|c|c|c|c|c|c|c|c|}
\hline \multirow{2}{*}{$\begin{array}{c}\text { Staż pracy } \\
\text { nauczycielskiej }\end{array}$} & \multicolumn{6}{|c|}{ Częstotliwość modyfikacji scenariuszy } \\
\cline { 2 - 9 } & \multicolumn{2}{|c|}{ zawsze } & \multicolumn{2}{c|}{ często } & \multicolumn{2}{c|}{ czasami } & \multicolumn{2}{c|}{ nigdy } \\
\cline { 2 - 9 } & $\mathrm{L}$ & $\%$ & $\mathrm{~L}$ & $\%$ & $\mathrm{~L}$ & $\%$ & $\mathrm{~L}$ & $\%$ \\
\hline 0-5 lat & 0 & 0,0 & 0 & 0,0 & 3 & 100,0 & 0 & 0 \\
\hline 6-10 lat & 0 & 0,0 & 0 & 0,0 & 7 & 100,0 & 0 & 0 \\
\hline 11-15 lat & 0 & 0,0 & 0 & 0,0 & 9 & 100,0 & 0 & 0 \\
\hline 15-20 lat & 0 & 0,0 & 0 & 0,0 & 6 & 100,0 & 0 & 0 \\
\hline 20 i więcej & 0 & 0,0 & 3 & 42,8 & 4 & 57,2 & 0 & 0 \\
\hline
\end{tabular}

Tabela 6. Częstotliwość modyfikacji scenariusz z uwzględnieniem stopnia awansu zawodowego

\begin{tabular}{|l|c|c|c|c|c|c|c|c|}
\hline \multirow{2}{*}{$\begin{array}{c}\text { Stopień awansu } \\
\text { zawodowego }\end{array}$} & \multicolumn{8}{|c|}{ Częstotliwość modyfikacji scenariuszy } \\
\cline { 2 - 9 } & \multicolumn{2}{|c|}{ zawsze } & \multicolumn{2}{c|}{ często } & \multicolumn{2}{c|}{ czasami } & \multicolumn{2}{c|}{ nigdy } \\
\cline { 2 - 9 } & $\mathrm{L}$ & $\%$ & $\mathrm{~L}$ & $\%$ & $\mathrm{~L}$ & $\%$ & $\mathrm{~L}$ & $\%$ \\
\hline kontraktowy & 0 & 0,0 & 0 & 0,0 & 5 & 100,0 & 0 & 0 \\
\hline mianowany & 0 & 0,0 & 0 & 0,0 & 21 & 100,0 & 0 & 0 \\
\hline dyplomowany & 0 & 0,0 & 3 & 50,0 & 3 & 50,0 & 0 & 0 \\
\hline
\end{tabular}

Wszyscy ankietowani nauczyciele kontraktowi i mianowani czasami modyfikują scenariusze. Nauczyciele dyplomowani, jak wynika z zestawienia podzielili się po połowie - po $50 \%$ często lub czasami dokonują zmian w zastanych propozycjach. Wyniki mogą więc sugerować, że gotowe scenariusze zajęć nie zawsze w pełni zadowalają nauczycieli. Powoduje to zapewne konieczność dostosowania wymagań i materiału nauczania do potrzeb i możliwości zespoku klasowego. Rozszerzanie i modyfikowanie gotowych propozycji korzystnie podnosi poziom prowadzonych zajęć, a czerpanie pomysłów na zajęcia $\mathrm{z}$ różnych źródeł sprawia, że zajęcia $\mathrm{z}$ dziećmi są bardziej interesujące, nie należą do schematycznych. Nauczyciele rozpoczynając starania o uzyskanie wyższego stopnia awansu zawodowego podejmują różnorodne formy doskonalenia zawodowego. Kursy i warsztaty dostarczają nowych, ciekawych pomysłów na rozwiązywanie problemów edukacyjnych i skuteczne metody ksztakcenia.

Treści programowe i metody ich opracowywania podzielone zostały w przewodnikach na poszczególne obszary edukacji: społeczno przyrodniczej, polonistycznej, matematycznej, muzycznej, plastycznej, technicznej i motoryczno-ruchowej. Zebrałam opinie dotyczące wszystkich obszarów wielokierunkowej aktywności uczniów. Ocenę zasobów rozwiązań w poszczególnych obszarach przedstawiam w tabeli 7 . 
Tabela 7. Ocena zasobów rozwiązań metodycznych proponowanych w przewodnikach

\begin{tabular}{|l|c|c|c|c|c|c|c|c|}
\hline \multirow{2}{*}{ Obszar edukacji } & \multicolumn{2}{|c|}{ zbyt obszerny } & \multicolumn{2}{c|}{ odpowiedni } & \multicolumn{2}{c|}{ wystarczający } & \multicolumn{2}{c|}{ niewystarczający } \\
\cline { 2 - 10 } & $\mathrm{L}$ & $\%$ & $\mathrm{~L}$ & $\%$ & $\mathrm{~L}$ & $\%$ & $\mathrm{~L}$ & $\%$ \\
\hline $\begin{array}{l}\text { Edukacja społeczno- } \\
\text { przyrodnicza }\end{array}$ & 0 & 0,0 & 9 & 28,1 & 13 & 40,6 & 10 & 31,3 \\
\hline $\begin{array}{l}\text { Edukacja } \\
\text { polonistyczna }\end{array}$ & 0 & 0,0 & 21 & 65,6 & 11 & 34,4 & 0 & 0,0 \\
\hline $\begin{array}{l}\text { Edukacja } \\
\text { matematyczna }\end{array}$ & 0 & 0,0 & 15 & 46,8 & 17 & 53,2 & 0 & 0,0 \\
\hline Edukacja muzyczna & 0 & 0,0 & 12 & 37,5 & 20 & 62,5 & 0 & 0,0 \\
\hline Edukacja plastyczna & 0 & 0,0 & 7 & 21,9 & 14 & 43,7 & 11 & 34,4 \\
\hline Edukacja techniczna & 0 & 0,0 & 0 & 0 & 18 & 56,3 & 14 & 43,7 \\
\hline $\begin{array}{l}\text { Edukacja } \\
\text { motoryczno-ruchowa }\end{array}$ & 0 & 0,0 & 9 & 28,1 & 8 & 25,0 & 15 & 46,9 \\
\hline
\end{tabular}

W dziedzinie edukacji społeczno-przyrodniczej zdaniem 28,1\% osób zasób rozwiązań metodycznych jest odpowiedni, dla 40,6\% wystarczający. Aż 31,3\% osób nie jest zadowolonych z proponowanych rozwiązań. Zarówno w zakresie edukacji polonistycznej $(65,6 \%$ badanych uważa, za odpowiedni, $34,4 \%$ osób zaś, że jest wystarczający), matematycznej (zakres odpowiedni 46,8\% ankietowanych, wystarczający 53,2\%), jak i muzycznej ( $37,5 \%$ odpowiedni, 62,5\% wystarczający), opinie na ten temat są pozytywne i zadowalające. Nauczyciele nie zauważają braków i nie mają do proponowanych rozwiązań metodycznych zastrzeżeń. Można to odnieść do wcześniejszej analizy częstotliwości modyfikowania proponowanych scenariuszy. Aż $90,6 \%$ badanych przyznała, że tylko czasami dokonuje zmian w gotowych planach zajęć, zatem zasób rozwiązań jest dla nauczycieli satysfakcjonujący.

Natomiast ocena zakresu propozycji w tematyce edukacji plastycznej, technicznej oraz motoryczno ruchowej jest już bardziej zróżnicowana. Pojawiają się opinie negatywne. Odpowiednio w zakresie edukacji plastycznej aż 34,4\% badanych uznało proponowane metody za niezadowalające, $w$ edukacji technicznej i motoryczno ruchowej takich osób znalazło się aż 46,9\%.

Istotną kwestią w podjętych badaniach są poglądy nauczycieli na temat treści zawartych $\mathrm{w}$ przewodnikach metodycznych. Trudnym pytaniem okazało, się wskazanie przez pedagogów treści, które w ich opinii nie powinny znaleźć się w przewodnikach. Zdaniem 34,4\% osób w ogóle nie ma takich treści, które powinny zostać z nich usunięte, aż $65,6 \%$ osób nie potrafiło udzielić odpowiedzi na to pytanie. W czasie, kiedy prowadziłam badania w klasie I obowiązywała już nowa podstawa programowa, której nie odzwierciedlają podręczniki i karty 
pracy. Nowa podstawa znacznie ograniczyła między innymi treści matematyczne, wprowadziła nowy zestaw lektur. Być może nauczyciele oczekują zapowiadanych zmian, które zmierzać będą do zmniejszenia zakresu treści programowych przewidzianych do realizacji na I etapie edukacji. Dane uzyskane w trakcie badań ankietowych w przypadku opinii nauczycieli na temat tego, jakie powinny znaleźć się treści $\mathrm{w}$ oferowanych przewodnikach prezentuję w tabeli 8 .

Tabela 8. Brakujące treści w przewodnikach metodycznych

\begin{tabular}{|l|c|c|}
\hline \multicolumn{1}{|c|}{ Treści przewodników metodycznych } & L* & $\%$ \\
\hline zadania techniczne inne niż prace wykonane z papieru & 19 & 59,4 \\
\hline ćwiczenia ruchowe & 13 & 40,6 \\
\hline $\begin{array}{l}\text { propozycje utrwalania wprowadzonego materialu np. ćwiczenia } \\
\text { ortograficzne, gramatyczne, przyrodnicze }\end{array}$ & 13 & 40,6 \\
\hline mało propozycji ciekawych prac plastycznych & 11 & 34,4 \\
\hline treści dotyczące krajów Unii Europejskiej & 9 & 28,1 \\
\hline propozycje zapisu np. listu, opisu & 4 & 12,5 \\
\hline rozwiązania niektórych zadań & 3 & 9,4 \\
\hline brak odpowiedzi & 6 & 18,8 \\
\hline
\end{tabular}

*Pytanie otwarte - stąd liczba wszystkich odpowiedzi nie sumuje się do $100 \%$

Zdaniem nauczycieli, w wykorzystywanych przewodnikach metodycznych brakuje szerszej gamy zadań technicznych, które zwykle są ograniczone do zadań wykonywanych z papieru, tak uważa aż 59,4\% badanych, $40,6 \%$ ankietowanym brakuje ciekawych ćwiczeń ruchowych. W obszarze edukacji polonistycznej i społeczno-przyrodniczej brakuje propozycji utrwalania wprowadzonego materiału z zakresu ortografii, gramatyki i przyrody. 34,4\% osób chciałoby, aby w przewodnikach znalazło się więcej różnorodnych propozycji prac plastycznych. Badani dostrzegają też potrzebę wprowadzenia treści dotyczących krajów Unii Europejskiej $(28,1 \%)$.

Interesujące było również uzyskanie informacji na temat tego, z jakich części przewodników dla nauczycieli najczęściej korzystają ich odbiorcy. Dane w tym zakresie zaprezentuję w kolejnym zestawieniu (tabela 9).

Dużą zgodność wśród nauczycieli można zauważyć w ocenie przydatności poszczególnych części przewodników metodycznych. Wszyscy badani uznali, że szczegółowe scenariusze zajęć oraz propozycje zapisu tematów zajęć do dziennika są najbardziej przydatne. 90,6\% korzysta ze szczegółowych rozkładów materiału. $34,4 \%$ osób uważa za potrzebne przewidywane osiągnięcia uczniów. 
Tabela 9. Korzystanie przez nauczycieli z poszczególnych części przewodników

\begin{tabular}{|l|c|c|}
\hline \multirow{2}{*}{ Tytuł części przewodnika } & \multicolumn{2}{c|}{ Wybór nauczycielski } \\
\cline { 2 - 3 } & L & $\%$ \\
\hline Szczegółowe scenariusze zajęć & 32 & 100,0 \\
\hline Propozycja zapisu w dzienniku lekcyjnym & 32 & 100,0 \\
\hline Szczegółowy rozkład materiału & 29 & 90,6 \\
\hline Przewidywane osiagnięcia uczniów - plany wynikowe & 11 & 34,4 \\
\hline Inne - oprawy zajęć ruchowych & 1 & 3,1 \\
\hline
\end{tabular}

*Każdy nauczyciel miał prawo wyboru wielu odpowiedzi - stąd liczba wszystkich odpowiedzi nie sumuje się do $100 \%$

Zastanawiający był również fakt $\mathrm{z}$ jakich części korzystają nauczyciele o różnym stażu pracy i różnym stopniu awansu zawodowego. Dane te prezentuję w tabeli 10 i 11.

Tabela 10. Części przewodników najczęściej używane przez nauczycieli ze względu na długość stażu pracy

\begin{tabular}{|c|c|c|c|c|c|c|c|c|c|c|}
\hline \multirow{3}{*}{$\begin{array}{c}\text { Tytuł } \\
\text { części przewodnika }\end{array}$} & \multicolumn{10}{|c|}{ Staż pracy nauczycieli* } \\
\hline & \multicolumn{2}{|c|}{$0-5$ lat } & \multicolumn{2}{|c|}{$6-10$ lat } & \multicolumn{2}{|c|}{ 11-15 lat } & \multicolumn{2}{|c|}{ 16-20 lat } & \multicolumn{2}{|c|}{21 i więce } \\
\hline & $\mathrm{L}$ & $\%$ & $\mathrm{~L}$ & $\%$ & $\mathrm{~L}$ & $\%$ & $\mathrm{~L}$ & $\%$ & $\mathrm{~L}$ & $\%$ \\
\hline $\begin{array}{l}\text { Szczegółowe scenariusze } \\
\text { zajęć }\end{array}$ & 3 & 100,0 & 7 & 100,0 & 9 & 100,0 & 6 & 100,0 & 7 & 100,0 \\
\hline $\begin{array}{l}\text { Propozycja zapisu w } \\
\text { dzienniku lekcyjnym }\end{array}$ & 3 & 100,0 & 7 & 100,0 & 9 & 100,0 & 6 & 100,0 & 7 & 100,0 \\
\hline $\begin{array}{l}\text { Szczegółowy rozkład } \\
\text { materiału }\end{array}$ & 3 & 100,0 & 7 & 100,0 & 9 & 100,0 & 6 & 100,0 & 4 & 57,1 \\
\hline $\begin{array}{l}\text { Przewidywane osiagnięcia } \\
\text { uczniów - plany wyniko- } \\
\text { we }\end{array}$ & 3 & 100,0 & 7 & 100,0 & 1 & 11,1 & 0 & 0 & 0 & 0 \\
\hline $\begin{array}{l}\text { Inne - zestawy zajęć } \\
\text { ruchowych }\end{array}$ & 1 & 33,3 & 0 & 0 & 0 & 0 & 0 & 0 & 0 & 0 \\
\hline
\end{tabular}

*Każdy nauczyciel miał prawo wyboru wielu odpowiedzi - stąd liczba wszystkich odpowiedzi nie sumuje się do $100 \%$

Analizując korzystanie z różnych części przewodników ze względu na długość stażu pracy widzimy, że tylko $42,9 \%$ nauczycieli z najdłuższym, ponad 20-letnim stażem nie korzysta ze szczegółowych rozkładów materiału. Plany wynikowe potrzebne są nauczycielom ze stażem najkrótszym - do 10 lat. Początkujący nauczyciel uznał za potrzebne zestawy zajęć ruchowych. 
Tabela 11. Części przewodników najczęściej używane przez nauczycieli ze względu na posiadany stopień awansu zawodowego

\begin{tabular}{|c|c|c|c|c|c|c|}
\hline \multirow{3}{*}{ Tytuł części przewodnika } & \multicolumn{6}{|c|}{ Stopień awansu zawodowego nauczycieli* } \\
\hline & \multicolumn{2}{|c|}{ kontraktowy } & \multicolumn{2}{|c|}{ mianowany } & \multicolumn{2}{|c|}{ dyplomowany } \\
\hline & $\mathrm{L}$ & $\%$ & $\mathrm{~L}$ & $\%$ & $\mathrm{~L}$ & $\%$ \\
\hline Szczegółowe scenariusze zajęć & 5 & 100,0 & 21 & 100,0 & 6 & 100,0 \\
\hline Propozycja zapisu w dzienniku lekcyjnym & 5 & 100,0 & 21 & 100,0 & 6 & 100,0 \\
\hline Szczegółowy rozkład materiału & 5 & 100,0 & 21 & 100,0 & 3 & 50,0 \\
\hline $\begin{array}{l}\text { Przewidywane osiągnięcia uczniów- plany } \\
\text { wynikowe }\end{array}$ & 5 & 100,0 & 6 & 28,6 & 0 & 0 \\
\hline Inne - zestawy zajęć ruchowych & 1 & 33,3 & 0 & 0 & 0 & 0 \\
\hline
\end{tabular}

*Każdy nauczyciel miał prawo wyboru wielu odnowiedzi - stąd liczba wszystkich odpowiedzi nie sumuje się do $100 \%$

Stopień awansu zawodowego również ma znaczenie jeżeli chodzi o wskazanie potrzebnych części przewodnika. Ze szczegółowego rozkładu materiału korzysta tylko 50\% nauczycieli dyplomowanych, natomiast nie korzystają oni z planów wynikowych. Spośród nauczycieli mianowanych tylko $28,6 \%$ sięga po plany wynikowe. Nauczyciel kontraktowy prowadzi zajęcia ruchowe w oparciu o zestawy proponowane w przewodniku.

Budowa scenariuszy zakłada zrealizowanie wszystkich ćwiczeń zawartych w pakiecie dla ucznia. Od pewnego czasu w kształceniu zintegrowanym panuje „kartomania”. Nauczyciele odczuwają swoistą presję ze strony rodziców oraz dyrekcji na wypełnienie wszystkich ćwiczeń zawartych w kartach pracy. Wprowadzanie zmian w scenariuszu prowadzić musi do pominięcia niektórych propozycji autorów podręczników, a ćwiczenia nie zrealizowane często świadczą na niekorzyść nauczyciela.

Propozycje zapisów w dzienniku są niewątpliwym ułatwieniem dla pedagogów obciążonych pisemnym opracowywaniem różnorodnych materiałów. Nauczyciele, oprócz zajęć dydaktycznych, pracują w zespołach problemowych zajmujących się opracowywaniem wskaźników i kryteriów wewnętrznego mierzenia jakości pracy szkoły, zespołach tworzących wewnątrzszkolne systemy oceniania, programy naprawcze, profilaktyczne i wychowawcze. Przewidywane bieżące osiagnięcia uczniów znacznie ułatwiają redagowanie wpisów i semestralnych ocen opisowych w dziennikach lekcyjnych.

Ze względu na fakt, że nauczyciele korzystają z gotowych scenariuszy zajęć proponowanych $\mathrm{w}$ przewodnikach istotne było również sprawdzenie jakie metody pracy stosują podczas zajęć dydaktyczno-wychowawczych na etapie edukacji wczesnoszkolnej. Scenariusze zajęć nie dostosowują przecież materiału 
do właściwości i możliwości uczniów w konkretnej klasie, a jedynie proponują realizowanie procesu kształcenia za pomocą różnych metod i środków dydaktycznych dostosowując je do celów zajęć i materiału nauczania. Wyniki tych badań prezentuję w tabeli 12 .

Tabela 12. Metody nauczania stosowane przez nauczycieli

\begin{tabular}{|c|c|c|c|}
\hline Rodzaje metod & Metody stosowane przez nauczycieli & $\mathrm{L}$ & $\%$ \\
\hline 1 & 2 & 3 & 4 \\
\hline \multirow{6}{*}{$\begin{array}{l}\text { Metody oparte na } \\
\text { słowie }\end{array}$} & pogadanka & 32 & 100,0 \\
\hline & objaśnienia & 32 & 100,0 \\
\hline & praca z książką & 32 & 100,0 \\
\hline & opis & 31 & 96,9 \\
\hline & opowiadanie & 30 & 93,7 \\
\hline & dyskusja & 11 & 34,4 \\
\hline \multirow{4}{*}{$\begin{array}{l}\text { Metody oparte na } \\
\text { obserwacji i pomiarze }\end{array}$} & pokaz & 31 & 96,9 \\
\hline & obserwowanie okazów naturalnych i zjawisk & 30 & 93,7 \\
\hline & mierzenie & 25 & 78,2 \\
\hline & ważenie & 24 & 75,0 \\
\hline \multirow{7}{*}{$\begin{array}{l}\text { Metody oparte na } \\
\text { działaniach praktycz- } \\
\text { nych }\end{array}$} & ćw iczenia & 32 & 100,0 \\
\hline & zadania & 30 & 93,7 \\
\hline & działalność plastyczna & 27 & 84,4 \\
\hline & doświadczenia & 18 & 56,3 \\
\hline & działalność techniczna & 14 & 43,8 \\
\hline & zajęcia kulinarne & 11 & 34,4 \\
\hline & wykonywanie projektów & 9 & 28,1 \\
\hline \multirow{10}{*}{ Metody aktywizujące } & drama & 32 & 100,0 \\
\hline & burza mózgów & 30 & 93,7 \\
\hline & zabawy integracyjne & 28 & 87,5 \\
\hline & inscenizacje & 27 & 84,4 \\
\hline & praca we współpracy & 27 & 84,4 \\
\hline & łańcuch skojarzeń & 9 & 28,1 \\
\hline & mapy pojęciowe & 9 & 28,1 \\
\hline & słoneczko & 7 & 21,9 \\
\hline & kula śniegowa & 7 & 21,9 \\
\hline & gwiazda pytań & 5 & 15,6 \\
\hline \multirow{3}{*}{ Gry dydaktyczne } & zagadki i rebusy & 31 & 96,9 \\
\hline & plątaninki & 29 & 90,6 \\
\hline & gry matematyczne & 26 & 81,3 \\
\hline
\end{tabular}


Tabela 12 (cd.)

\begin{tabular}{|l|l|c|c|}
\hline \multicolumn{1}{|c|}{1} & \multicolumn{1}{|c|}{2} & 3 & 4 \\
\hline \multirow{4}{*}{ Gry dydaktyczne } & gry ortograficzne & 24 & 75,0 \\
\cline { 2 - 4 } & gry planszowe & 12 & 37,5 \\
\cline { 2 - 4 } & domina & 11 & 34,4 \\
\cline { 2 - 4 } & gry dotyczące ruchu drogowego & 5 & 15,6 \\
\hline \multirow{4}{*}{ Inne } & wycieczki & 23 & 71,9 \\
\cline { 2 - 4 } & wystawa prac & 19 & 59,4 \\
\cline { 2 - 4 } & konkursy & 17 & 53,1 \\
\hline
\end{tabular}

*Pytanie otwarte - stąd liczba wszystkich odpowiedzi nie sumuje się do 100\%

Jak wynika z prezentowanego $\mathrm{w}$ tabeli 12 . zestawienia nauczyciele $\mathrm{w}$ pracy stosują wiele różnych metod. Zdecydowanie niestety dominują jednak metody oparte na słowie. W grupie metod opartych na słowie wszyscy ankietowani wymienili pogadankę, objaśnienia oraz pracę z książką. Ponad 90,0\% badanych nauczycieli stosuje w pracy z uczniami opis i opowiadanie. Co trzeci ankietowany pracuje metodą dyskusji.

Spośród metod opartych na obserwacji i pomiarze 96,9\% badanych wykorzystuje pokaz, 93,7\% obserwowanie okazów naturalnych i zjawisk. Mierzenie i ważenie stosuje ponad $75,0 \%$ nauczycieli.

Metody ćwiczeń i zadań w grupie metod opartych na działaniach praktycznych wymieniają prawie wszyscy nauczyciele. $84,4 \%$ osób wskazuje działalność plastyczną, a 56,3\% stosuje w swojej pracy doświadczenia. Mniej niż połowa ankietowanych $\mathrm{w}$ tej grupie metod wymieniła działalność techniczną $(43,8 \%)$, zajęcia kulinarne $(34,4 \%)$, a $28,1 \%$ pracuje metodą projektów. Spośród metod aktywizujących powszechnie stosowana jest drama (100\%), niewiele mniej bo 93.7\% badanych wymienia burzę mózgów. 87,5\% nauczycieli prowadzi zabawy integracyjne, a $84,4 \%$ organizuje inscenizacje i pracę w grupach. Do mniej znanych metod należą: łańcuch skojarzeń i mapy pojęciowe, które wymienia $28,1 \%$ ankietowanych oraz słoneczko i kula śniegowa stosowane przez $21,9 \%$ badanych. W kształceniu zintegrowanym popularne są również gry dydaktyczne. Zagadki, rebusy i plątaninki stosuje ponad $90 \%$ badanych. Często stosowane są gry matematyczne i ortograficzne. Wymienia je odpowiednio 81,3\% i 75,0\% ankietowanych. Co trzeci badany prowadzi zajęcia $\mathrm{z}$ zastosowaniem gier planszowych i domina. 15,6\% wymienia gry dotyczące ruchu drogowego. Wśród innych stosowanych metod badani wymienili wycieczki $(73,9 \%)$, wystawy prac $(59,4 \%)$ i konkursy $(53,1 \%)$. 


\section{Interpretacje, refleksje i wnioski z badań}

Warsztat pracy nauczyciela to precyzyjnie dobrane do poszczególnych celów programowych zasoby informacyjne, środki dydaktyczne i narzędzia, za pomocą których to elementów powinien zrealizować skutecznie całość procesu dydaktyczno-wychowawczego na poziomie edukacji wczesnoszkolnej. Stosowane zatem przez nauczyciela rozwiązania metodyczne zależeć będą od jego kompetencji dydaktyczno-metodycznych, które zdobywa opanowując całe bogactwo metod nauczania. Edukacja nauczycielska dowodzi, że nauczyciel powinien przekraczać ramy swojej profesji, a więc konwencjonalny zakres kompetencji dydaktycznych. Konieczna jest specjalna wrażliwość nauczyciela na indywidualne potrzeby rozwojowe (biologiczne, psychiczne, emocjonalne) dziecka oraz głębokie rozumienie jego problemów ${ }^{13}$.

Nauczyciele kształcenia zintegrowanego systematycznie korzystają z przewodników metodycznych opracowanych przez autorów pakietów edukacyjnych. Można przyjąć, że tym samym obdarzają autora wybranego przez siebie pakietu zaufaniem, co do jakości publikacji, którą otrzymują. Same wydawnictwa zapewniają o zgodności zarówno programów, jak i podręczników z aktualnie obowiązującą podstawą programową. Zachęcając do wyboru swoich pakietów edukacyjnych wydawnictwa prześcigają się w dostarczaniu nauczycielom coraz to bogatszej oferty pomocy demonstracyjnych i materiałów metodycznych dla nauczycieli. Przy okazji organizując warsztaty i szkolenia dotyczące aktywizujących metod pracy i wykorzystywania przygotowanych pomocy dydaktycznych. Z pewnością pozytywnym zjawiskiem, które zaobserwować można na podstawie wypowiedzi badanych nauczycieli jest to, że przygotowując się do zajęć nie ograniczają się jedynie do scenariuszy zajęć zaproponowanych $\mathrm{w}$ przewodnikach. Starają się analizować swoją wiedzę merytoryczną i metodyczną w oparciu o różnego rodzaju publikacje książkowe i artykuły w czasopismach pedagogicznych. Wynika to z konieczności dostosowania wymagań do potrzeb i możliwości edukacyjnych uczniów, z którymi pracują. Taka postawa z pewnością sprzyja skuteczności nauczania ${ }^{14}$.

Przygotowane i przeprowadzone badania empiryczne pokazały, że nauczyciele stosują z uczniami różne metody nauczania, z który wiele zostało również zaproponowanych w szczegółowych scenariuszach zajęć. Liczna grupa ankietowanych zmienia zastane i proponowane plany zajęć. Można mieć nadzieję, że wynika to z potrzeby dostosowania do środowiska, w którym pracują. Badani

13 D. Waloszek, Pedagogika przedszkolna. Metamorfoza statusu i przedmiotu badań, Kraków 2006.

${ }^{14}$ Badania dotyczące spełniania oczekiwań nauczycieli przez przewodniki metodyczne oraz badania dotyczące opinii pedagogów na temat struktury tychże przewodników prezentuję w artykule: Przewodniki metodyczne w opinii nauczycieli edukacji wczesnoszkolnej, [w:] R. Burkovičová (red.), Aktuální otázky preprimárního a primárního vzdělávání, Ostrawa, 2010. 
nauczyciele na ogół pozytywnie oceniają zasób treści merytorycznych i rozwiązań metodycznych proponowanych w przewodnikach dla danego pakietu edukacyjnego. Sugerują nieliczne braki, jakie dostrzegaja w proponowanych materiałach, w zakresie edukacji plastycznej, technicznej oraz motoryczno-ruchowej. Zwrócili także uwagę w trakcie wypełniania ankiet na niewystarczający zakres treści o krajach Unii Europejskiej, niedostateczny zakres treści ortograficznych, gramatycznych oraz niepełny zakres wiedzy przyrodniczej.

Zastanawiający jest jednak fakt, że każdy z badanych nauczycieli jako najlepszy wybrał materiał, na którym aktualnie pracował, nie dokonując żadnych porównań z innymi, dotychczas wykorzystywanymi publikacjami. Warto więc zastanowić się nad tym w szerszym aspekcie organizując podobne badania, w których respondenci dokonaliby również i takich porównań. Istotne byłyby wówczas opinie nauczycieli wynikające z przyczyn zmiany wykorzystywanego pakietu edukacyjnego lub też przyczyn pozostawania przy tym samym pakiecie w kolejnych cyklach kształcenia zintegrowanego. Jak wiadomo bowiem, nie zawsze nauczyciel ma dowolność $\mathrm{w}$ wyborze materiałów do pracy $\mathrm{z}$ dziećmi, czasem jest mu on narzucony $\mathrm{z}$ góry. A jak wynika z przedstawionych $\mathrm{w}$ niniejszej publikacji badań empirycznych, żaden z opiniowanych przewodników metodycznych nie uzyskał najwyższej z możliwych ocen. Co oznacza, że poradniki w oczach wykorzystujących ich nauczycieli w dalszym ciągu wymagają udoskonalenia ich i to zarówno pod względem merytorycznym, jak i pod kątem metodycznych rozwiązań proponowanych w publikacjach.

Na bazie opracowanego materiału uzyskanego podczas badań można zatem sformułować wnioski końcowe.

1. Nauczyciele niezależnie od stażu pracy i stopnia awansu zawodowego chętnie korzystają z przewodników i poradników metodycznych.

2. Proponowane scenariusze twórczo modyfikują, wzbogacając je treściami merytorycznymi z innych źródeł oraz autorskimi rozwiązaniami metodycznymi.

3. Nauczyciele kształcenia zintegrowanego stosują różnorodne tradycyjne i aktywizujące metody nauczania.

4. Przewodniki zawierają niewystarczający zasób treści merytorycznych zwłaszcza w obszarze edukacji plastycznej i technicznej oraz treści dotyczących krajów Unii Europejskiej.

5. Bezpośredni kontakt przedstawicieli wydawnictwa $\mathrm{z}$ nauczycielami oraz organizowanie szkoleń i warsztatów skutecznie wpływa na wzrost zainteresowania proponowanym pakietem edukacyjnym.

6. Oczekiwania nauczycieli najpełniej spełniają przewodnik i pakiet edukacyjny Wesota szkoła wydawnictwa WSiP.

Na polskim rynku wydawniczym nieustannie pojawiają się nowe kompendia metodyczne skierowane do nauczycieli edukacji wczesnoszkolnej. Spora część z nich niestety pozostawia wiele do życzenia zarówno pod kątem meto- 
dycznym, jak i merytorycznym. Najczęściej spotykamy gotowe rozkłady materiału zawierające również określone, często miernej jakości wzory prowadzenia zajęć w postaci scenariuszy na każdy dzień pobytu dziecka w szkole. Takie materiały dostarczają nauczycielom wydawnictwa oferując je do wydawanych przez siebie pakietów edukacyjnych. Wiadomo, że nauczyciel nie musi i nie jest w stanie za każdym razem samodzielnie opracowywać wszystkie elementy codziennych zajęć w procesie dydaktyczno-wychowawczym prowadzonym we własnej klasie. Jednakże zamiast bezmyślnego kopiowania gotowych pomysłów jego indywidualna praca powinna wyrażać się umiejętnym doborem i adekwatnq aplikacja do wtasnej praktyki istniejacych już rozwiaza ${ }^{15}$. Tylko przy takim założeniu przewodnik metodyczny może stać się odpowiednim narzędziem w rękach nauczyciela, którego zadaniem jest stwarzanie warunków do samodzielnego zdobywania wiedzy przez uczniów oraz inicjowanie różnego rodzaju aktywności dzieci na szczeblu kształcenia zintegrowanego.

Najnowsze koncepcje edukacyjne definiują proces kształcenia jako układ czynności nauczyciela i uczniów, w którym zadaniem nauczyciela jest stwarzanie warunków do samodzielnego zdobywania wiedzy przez uczniów oraz inicjowanie różnego rodzaju aktywności. Proces ten odbywać się powinien na każdym szczeblu nauczania. Także na początkowym etapie kształcenia i wychowania w edukacji przedszkolnej, która ma decydujące znaczenie dla późniejszej kariery szkolnej dziecka. Skuteczne planowanie wymaga od nauczyciela wielu kompetencji dydaktyczno-metodycznych, respektowania zasad kształcenia, świadomości wymagań określonych w podstawie programowej na szczeblu centralnym i programach przyjętych $\mathrm{w}$ danej szkole, znajomości decyzji podjętych w różnych zespołach problemowych funkcjonujących w szkole oraz rozumienia potrzeb i zainteresowań uczniów ${ }^{16}$.

Powinno się więc dążyć do tego, by nauczyciele otrzymywali do swojej dyspozycji materiały metodyczne wysokiej jakości, które będą dla nich wskazówką do skutecznej pracy dydaktyczno-wychowawczej na każdym etapie edukacji. Takie materiały, które wyzwolą w nauczycielach chęci do stosowania metod pracy umożliwiających uczniom pokonywanie trudności, indywidualne tempo pracy, identyfikację $\mathrm{z}$ grupą oraz efektywną komunikację. Tak, aby nauczyciel potrafił pobudzać dzieci do działania poprzez kształtowanie badawczej postawy. Nie zapominając o tym, że takie materiały metodyczne mają traktować jedynie jako wskazówkę, inspirację do tworzenia indywidualnych scenariuszy zajęć w oparciu o potencjał własnych uczniów oraz możliwości środowiska, w którym pracują.

\footnotetext{
${ }^{15}$ D. Gołebniak, Nauczanie...., s. 197.

${ }^{16}$ A. Jakubowicz-Bryx, Przewodniki...
} 
ANNA JAKUBOWICZ-BRYX

\section{Methodological guides as a source of knowledge for teachers in early school education}

The last few years were a time when a number of publications and methodological guides for early school education teachers were launched on the Polish market. This paper presents a debate on the technical and methodological quality of such publications. The considerations are based on empirical surveys carried out among early school education teachers, assuming that a methodological guide is the right tool in a teacher's hands, whose task is to create conditions suitable for individual education of students and initiating various types of children's activity as far as integrated education is concerned. 